Jurnal Intelektualita: Keislaman, Sosial, dan Sains

Volume 7, Nomor 2, Desember 2018

ISSN: 2303-2952 (print)

DOI: https://doi.org/10.19109/intelektualita.v7i2.2724

\title{
Pembelajaran IPA Berbasis Tradisi Sains Islam di Madrasah
}

\author{
Erna Siti Nurhasanah \\ Program Studi Pendidikan Fisika \\ UIN Sunan Gunung Djati Bandung \\ Email: ernaasnf@gmail.com \\ Kokom Komalasari \\ Program Studi Pendidikan Fisika \\ UIN Sunan Gunung Djati Bandung \\ Email: malakomala09@gmail.com
}

\begin{abstract}
Abstrak
Banyak temuan ilmuwan muslim yang belum dimanfaatkan sebagai bahan ajar IPA di Madrasah Aliyah. Umumnya bahan ajar yang diberikan sama dengan bahan ajar di SMA. Tulisan ini bertujuan mengungkap temuan Muslim yang dapat digunakan sebagai bahan ajar IPA di Madrasah. Metode pembahasan yang digunakan dalam tulisan ini adalah sejarah sains berperspektif Islam dan metode pembelajaran sains demonstratif. Data dikumpulkan melalui kepustakaan. Hasil penelitian menunjukkan bahwa dalam bidang mekanik ilmuwan Muslim Al-Jazari yang mempengaruhi Banu Musa, al-Asturlabi, Hibat Allah Ibn al-Husayn dapat diajarkan di Madrasah Aliyah kelas XI. Tujuannya untuk memperkaya wawasan murid tentang IPA berperspektif Islam.
\end{abstract}

Kata Kunci: Mekanika Fluida, al-Jazari, Pembelajaran IPA

Sampai saat ini masih banyak baik di tingkat Madrasah Tsanawiyyah maupun Madrasah Aliyah yang menggunakan materi pelajaran IPA, khususnya dalam bidang fisika bersumber dari pemikiran para ilmuwan barat. Ilmuwan Islam terdahulu menemukan beberapa konsep fisika jauh sebelum ilmuwan barat menemukannya. Salah satu contohnya adalah materi tentang mekanika fluida yang dibahas oleh al-Jazari yang dipengaruhi oleh Banu Musa, al- Asturlabi, Hibat Allah Ibn al-Husayn [1].

Islam sering kali digambaran sebagai agama yang mundur dan memundurkan. Kenyataannya sejarah telah membuktikan betapa dunia Islam telah melahirkan banyak golongan sarjana dan ilmuwan yang sangat hebat dalam bidang falsafah, sains, politik, kesusasteraan, kemasyarakatan, agama, pengobatan, dan sebagainya. Pada zaman tersebut banyak ilmuwan Muslim yang menggunakan konsep wahyu memandu ilmu pada eksperimen yang dilakukannya. Secara historis konsep memandu ilmu digali dari spirit keilmuwan Islam klasik abad ke VII hingga XIII M yang non dikotomis (tidak kacamata kuda, antara ilmu yang satu dengan yang lain saling bersentuhan dan melingkupi).

Tujuan penulisan dari jurnal ini diantaranya untuk mengungkap kebenaran bahwan teori mekanika fluida merupakan hasil temuan ilmuwan Muslim, mempermudah pembelajaran mekanika fluida di Madrasah Aliyah, dan menjadi inspirasi bagi pelajar muslim.

Dalam mengungkap kebenaran bahwa teori mekanika fluida merupakan temuan ilmuwan Muslim, metode penelitian yang dilakukan adalah kepustakaan berupa 
pengumpulan bukti-bukti kebenaran tentang teori mekanika fluida dari beberapa sumber referensi.

\section{Hasil dan Pembahasan}

\section{Mekanika Fluida menurut al-Jazari}

Konsep robot modern sekarang, merupakan perkembangan dari konsep dasar yang ditemukan oleh ilmuan abad pertengahan. Seorang ilmuan Muslim, Abu al-'Iz Ismail bin Razaz al-Jazari (1136-1206) yang hidup pada abad ke-6 H, adalah orang pertama yang menemukan robot yang difungsikan untuk membantu pekerjaan rumah menggantikan pembantunya dalam menyediakan air wudhu untuk shalat.

Al-Jazari membuatkan suatu mesin (robot) yang mampu melakukan gerakan menuangkan (menunduk dan tegak kembali). Di tangan robot tersebut terdapat teko yang berisi air. Tangan yang lain menyediakan handuk. Dan di kepala robot tersebut terdapat seekor burung. Jika waktu shalat tiba, burung tersebut akan berkicau. Kemudian robot pun maju menuju tuannya. Lalu menuangkan air dari teko dengan takaran tertentu. Setelah selesai wudhu, robot itu akan memberikan handuk yang ada di tangannya. Kemudian kembali ke tempat semula. Gerakan terakhir ditutup dengan kicauan burung. [2]

Penemuan ini dicatat dalam Kitab al-Jazari: al-Jami' baina al-Ilmi wa al-Amal anNafi' fi Shina'ati al-Hil. Buku ini sudah diterjemahkan ke dalam bahasa Inggris pada tahun 1974 oleh Donald Hill, seorang insinyur dan sejarawan Inggris. Menurut George Sarton, buku al-Jazari ini adalah buku yang paling baik dalam bidangnya. Hal ini merupakan sebuah pencapaian yang tinggi seorang ilmuan Muslim (at-Turats al-Ilmi alIslami [2]

Al-Jazari merupakan ahli teknik yang luar biasa pada masanya. Dia tinggal di Diyar Bakir, Turki, selama abad-12. Ibnu Ismail Ibnu Al-Razzaz al-Jazari mendapat julukan sebagai Bapak 'Modern Engineering' berkat temuan-temuannya yang banyak mempengaruhi rancangan mesin-mesin modern saat ini, diantaranya combustion engine, crankshaft, suction pump, programmable automation.

Donald Routledge dalam bukunya Studies in Medieval Islamic Technology, mengatakan bahwa hingga zaman modern ini, tidak satupun dari suatu kebudayaan yang dapat menandingi lengkapnya instruksi untuk merancang, memproduksi dan menyusun berbagai mesin sebagaimana yang pernah disusun oleh Al-Jazari. [3]

\section{Rancangan Jam Gajah"Humanoid Automation"}

Di tahun 1206, al-Jazari membuat jam gajah yang bekerja dengan tenaga air dan berat benda untuk menggerakkan secara otomatis sistem mekanis, yang dalam interval tertentu akan memberikan suara simbal dan burung berkicau. Prinsip humanoid automation inilah yang mengilhami pengembangan robot masa sekarang. 


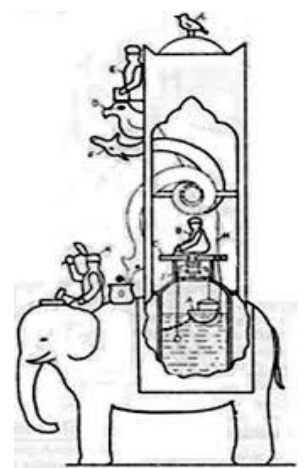

Figure 1 Jam Gajah "Humanoid Automation"

Beberapa peralatannya terinspirasi oleh peralatan-peralatan sebelumnya, seperti salah satu jam airnya yang monumental, yang berdasarkan Pseudo-Archimedes. Serta mengutip pengaruh Banu Musa bersaudara untuk air mancurnya, al-Asturlabi untuk desain jam lilin, dan Hibat Allah ibn al-Husayn (d. 1139) untuk musical automata. Teknologi automata Al-Jazari dikembangkan mencapai 50 jenis dan segala yang ditulis dan diilustrasikan dalam sangat legendaris, bukunya Bain Al Jami al-Ilm Wal 'Aml alNafi Fi Sinat' di al-Hiyal (The Book of pengetahuan dari cerdik mekanis Devices). Karya ini adalah mengenai teori dan praktik mekanika.Aspek paling penting dari mesin-mesin Al-Jazari adalah mekanisme, komponen, ide, metode, dan desain fitur yang dikerjakannya. Poros bubungan, pertama kali diperkenalkan tahun 1206 oleh al-Jazari, yang menerapkannya dalam Automaton ciptaannya, water clocks (such as the candle clock) and water-raising machines. Bubungan (cam) dan poros bubungan selanjutnya muncul dalam mekanik Eropa mulai abad ke-14 yang terkenal adalah The elephant clock atau 'jam gajah' yang terdiri dari jam hidrolik berbentuk gajah. Di atas gajah tersebut terdapat dekorasi berbentuk tenda mini yang menjadi tempat komponen jam hingga patung-patung yang bergerak dan berbunyi tiap setengah jam sekali. Jam gajah ini telah mengusung sebuah siklus mekanik yang secara otomatis menggerakkan seluruh bagian jam, mirip dengan dasar mekanika robot saat ini.[4]

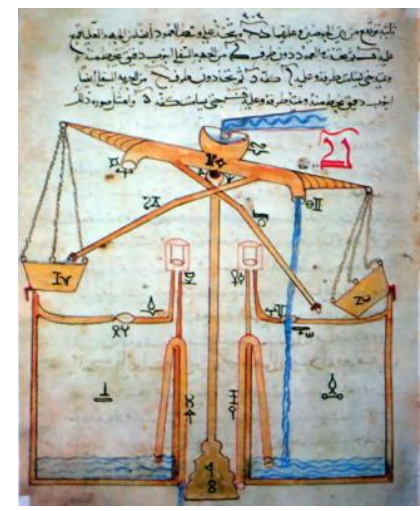

Al-Jazari memberikan kontribusi yang penting bagi dunia ilmu pengetahuan dan masyarakat. Mesin pemompa air yang dipaparkan dalam bukunya, menjadi salah satu karya yang inspiratif. Terutama bagi sarjana teknik dari belahan negeri Barat. Jika menilik sejarah, pasokan air untuk minum, keperluan rumah tangga, irigasi dan kepentingan 
industri merupakan hal vital di negara-negara Muslim. Namun demikian, yang sering menjadi masalah adalah terkait dengan alat yang efektif untuk memompa air dari sumber airnya. [5]

\section{Materi Mekanika Fluida di Madrasah Aliyah Kelas XI}

Mekanika Fluida adalah cabang dari ilmu fisika yang mempelajari mengenai zat fluida (cair, gas dan plasma) dan gaya yang bekerja padanya. Mekanika fluida dapat dibagi menjadi statika fluida, ilmu yang mempelajari keadaan fluida saat diam; kinematika fluida, ilmu yang mempelajari fluida yang bergerak; dan dinamika fluida, ilmu yang mempelajari efek gaya pada fluida yang bergerak.

a. Fluida Statika

Fluida statika adalah suatu zat dalam keadaan diam atau tidak bergerak. Berikut adalah hal-hal yang berkaitan dengan fluida statika.

1) Massa jenis

Massa jenis merupakan suatu ukuran kerapatan benda artinya, jika suatu benda mengalami massa jenis yang besar, maka benda tersebut memiliki kerapatan yang besar pula. Persamaannya adalah :

2) Tekanan

$$
\rho=\frac{m}{v}
$$

Tekanan (P) merupakan hasil bagi antara gaya $(\mathrm{F})$ dengan luas penampang (A) , dengan asumsi bahwa semakin besar gaya yang diberikan maka semakin besar pula tekanannya, akan tetapi sebaliknya, jika luas penampang besar, maka tekanan yang diberikan akan kecil. Dengan persamaan sebagai berikut :

3) Tekanan Hidrostatik

$$
P=\frac{F}{A}
$$

Tekanan hidrostatikmerupakan tekanan yang dihasilkan oleh suatu benda atau objek yang mengalami gravitasi ketika didalam fluida. Tekanan yang dihasilkan tergantung dari massa jenis fluida, percepatan gravitasi bumi dan ketinggian fluida. Persamaannya adalah sebagai berikut:

$$
P h=\rho, g, h
$$

4) Tekanan mutlak

Tekanan mutlakmerupakan tekanan dari keseluruhan total yang dialami benda atau objek, sehingga dapat dirumuskan:

Dengan :

$$
P=P_{0}+P_{h}
$$

$P=$ tekanan mutlak $(\mathrm{Pa})$

$P_{0}=$ Tekanan udara luar $(\mathrm{Pa})$

$P_{h}=$ Tekanan hidrostatik $(\mathrm{Pa})$

5) Hukum Pascal 
Hukum pascal berbunyi :" tekanan yang diberikankepada fluida dalamsebuah ruangan tertutup akan diteruskan sama besar ke segala arah."

$$
\begin{gathered}
\frac{F_{1}}{A_{1}}=\frac{F_{2}}{A_{2}} \\
F_{1}=\left(\frac{d_{1}}{d_{2}}\right), F_{2}
\end{gathered}
$$

Melalui persamaan hukum pascal diatas, bahwa hukum Pascal sering diaplikasikan pada alat-alat dongkrak hidrolik, mesin hidrolik, mesin hidrolik pengangkat mobil dan sistem kerja rem hidrolik pada mobil.

b. Fluida Dinamik

Fluida dinamik adalah fluida suatu zat( zat cair, gas) yang bergerak. Dalam hal ini fluida bersifat steady (mempunyai kecepatan yang konstan terhadap waktu), tak termampatkan (tidak mengalami perubahan volume), tidak kental, tidak turbulen (tidak mengalami putaran-putaran).Dalam kehidupan sehari-hari, banyak sekali hal - hal yang berkaitan dengan fluida dinamik ini, diantaranya:

1) Debit aliran (Q)

Jumlah volume fluida yang mengalir per satuan waktu, atau :

Dimana:

$$
Q=\frac{\Delta V}{\Delta T}=\frac{A v \Delta T}{\Delta T}=A v
$$

$Q=$ debit aliran $\left(\mathrm{m}^{3} / \mathrm{s}\right)$

$A=$ luas penampang $\left(\mathrm{m}^{2}\right)$

$V=$ laju aliran fluida $(\mathrm{m} / \mathrm{s})$

Aliran fluida sering dinyatakandalam debit aliran :

$$
Q=\frac{V}{t}
$$

Dimana :

$$
\begin{aligned}
& Q=\text { debit aliran }\left(\mathrm{m}^{3} / \mathrm{s}\right) \\
& V=\operatorname{volume}\left(\mathrm{m}^{3}\right) \\
& t=\operatorname{selang} \text { waktu }(\mathrm{s})
\end{aligned}
$$

2) Persamaan kontinuitas

Air yang mengalir didalam pipa air dianggap mempunyai debit yang sama disembarang titik . Atau jika ditinjau 2 tempat, maka :

Debit aliran $1=$ debit aliran 2

3) Hukum Bernoulli

Hukum Bernoulli adalah hukum yang berlandaskan pada hukum kekekalan energi yang dialami oleh aliran fluida. Hukum ini menyatakan bahwa jumlah tekanan (p), energi per satuan volume, dan energi potensial per satuan volume memiliki nilai yang sama pada setiap titik sepanjang suatu garis arus.Jika dinyatakan dalam persamaan menjadi:

$$
p_{1}+\frac{1}{2} \rho v_{1}^{2}+\rho g h_{1}=p_{2}+\frac{1}{2} \rho v_{2}^{2}+\rho g h_{2}
$$




$$
\begin{aligned}
& \text { Dimana : } \\
& p=\text { tekanan } \operatorname{air}(\mathrm{Pa}) \\
& v=\text { kecepatan } \operatorname{air}(\mathrm{m} / \mathrm{s}) \\
& g=\text { percepatan } \operatorname{gravitasi}\left(\mathrm{m} / \mathrm{s}^{2}\right) \\
& h=\text { ketinggian } \operatorname{air}(\mathrm{m})
\end{aligned}
$$

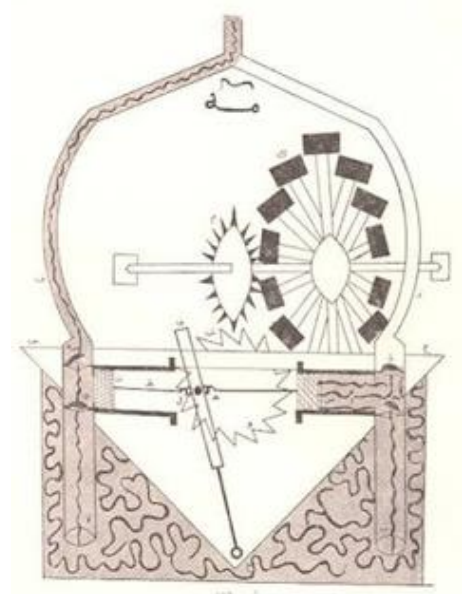

Figure 2 Aplikasi Mekanika Fluida Artesis

Aplikasi dari mekanika fluida yaitu : artesis yang merupakan mata air yang keluar sendiri tanpa perlu dipompa.

\section{Kesimpulan}

Berdasarkan hasil dan pembahasan ternyata teori mekanika fluida al-Jazari mendasari teori mekanika fluida di semua kelas XI di SMA maupun di Madrasah Aliyah. Tujuannya yaitu untuk memperkaya wawasan murid tentang IPA berperspektif Islam, memotivasi siswa untuk menjadi saintis muslim, umat Islam akan tersadarkan bahwa mereka punya sumber-sumber sains yang telah dikerjakan oleh ilmuwan mereka (muslim), dan bisa dikerjakkan oleh mahasiwa untuk PPL. 


\section{Daftar Pustaka}

[1] Irawan, Wahyu Memandu Ilmu Mazhab Keilmuan Nondikotomis, Bandung: UIN Sunan Gunung Djati Bandung.

[2] A. F. Basya, at-Turats al-Ilmi al-Islami, Dar al-Fikr al-Arabi., 2002.

[3] D. R. Hill, The Book of Knowledge of Ingenious Mechanical Devices, Boston USA, 1974.

[4] A. Uzun., Cizreli Eb-Ul-Iz ve Otomasyon Sistemleri, 2003.

[5] A.-J. I. al-Razzaz, The Book of Knowledge of Ingenious Mechanical Devices, Dordrecht: Reidel, 1974.

[6] U. A., Cizreli Eb-Ul-iz ve otomatik MAKINALARI, Esra Yayınları Konya, 1997. 
Erna Siti Nurhasanah, Kokom Komalasari

Pembelajaran IPA Berbasis Tradisi Sains Islam di Madrasah

Jurnal Intelektualita: Keislaman, Sosial, dan Sains Volume 7, Nomor 2, Desember 2018 